Dr IVANA DOBRIVOJEVIĆ, research fellow

Institute of Contemporary History

Trg Nikole Pašića 11, Belgrade

UDK 330.341.424:316.75(497.1)"194/195"

$329.78(497.1) " 194 / 195 "$

\title{
(IN)VOLUNTARY BUILDERS OF SOCIALISM. YOUNG WORKERS IN THE EARLY SOCIALIST YUGOSLAVIA*
}

\begin{abstract}
This paper examines the role of the youth in the industrialization of Socialist Yugoslavia during the first postwar decade. Special attention is paid to the Communist Party propaganda that embellished the reality of socialist factories and the forced mobilization of young men and women - the formation of work brigades. Both measures were supposed to secure the employment of much needed working force in the heavy industry. The study is based on archival sources kept in the Archive of Yugoslavia and the Archive of Serbia and selected periodicals.
\end{abstract}

KEY WORDS: Yugoslavia, industrialization, Five Year Plan, youth, forced mobilization

In the predominantly agrarian and underdeveloped country, modernization, industrialization and urbanization represented the necessary and inevitable processes. Despite certain, but slow, progress in the interwar period, extensive agriculture and primitive industry were hindering and preventing the true modernization and the increase in quality of life. Thus, Yugoslavia was increasingly lagging behind the developed European countries.

Shortly after seizing the power, Yugoslav communists focused on the radical social transformation. Carried away by revolutionary romanticism, Party leaders dreamt of shifting the boundaries of the possible since communism aroused faith and hope in the aftermath of the disaster. ${ }^{1}$ In

${ }^{*}$ Rad je deo projekta Srpsko društvo u jugoslovenskoj državi u 20. veku: između demokratije i diktature (177016), koji finansira Ministarstvo prosvete, nauke i tehnološkog razvoja Republike Srbije.

${ }^{1}$ Fransoa, Fire, Prošlost jedne iluzije. Komunizam u 20. veku (Beograd: Paidea, 1996), 13. 
every sphere of life (social, political and economic), the Soviet prototype was accepted as an ideal, 'and in many cases forced on the country with ruthless energy, regardless of the cost and human suffering'. ${ }^{2}$ The transformation of the society in accordance with the Soviet Stalinist model was the main goal Yugoslav communists strived for. Thus, it was acceptable to use 'forceful means' in order to prevent 'all those who wanted to hinder the construction of socialism'. ${ }^{3}$ The urge to transform the society immediately, 'to break and tear apart the backwardness that was accumulated trough the centuries', ${ }^{4}$ led to the instant modernization which was characterized by improvisation and formal, but not substantive, changing of old habits and customs and their adjustment to the new conditions.

Intoxicated with the revolutionary victory and the effective isolation of all political opponents, the leadership of the Yugoslav Communist Party mechanically copied the Soviet state and economic model, failing to anticipate the negative experiences and side effects that emerged from it. By early 1947, all the preparations for transition to long-term macroeconomic planning and rapid development of heavy industry had been completed. The Party leadership, as well as the Western governments, perceived Yugoslavia as the country of the greatest importance to the Soviet Union in the hierarchy of the communist countries. ${ }^{5}$ Although Yugoslavia, just like other European countries with the exception of Poland and Romania, had neither raw materials, ${ }^{6}$ nor financial resources to invest in expensive and only long-term viable heavy industrial plants, the Party had no doubts regarding the form and pace of industrialization. The Party leaders accepted Lenin's doctrine according to which heavy industry represented a prerequisite for building socialism. Thus, the extensive Five-Year Plan was created. It envisaged building of large industrial plants and the increase in national income by as much as 2,5 times in comparison with the pre-war level! ${ }^{7}$ However, the reasons for switching to planned economy which was

\footnotetext{
${ }^{2}$ Robert, Jarman, Yugoslavia. Political Diaries 1918 - 1965, v III (London: Archive Edition Ltd, 1997), 742.

${ }^{3}$ Josip, Broz Tito, Socijalistička demokratija mora imati snažnu ekonomsku podlogu, Govori i članci, v VI, (Zagreb: Naprijed, 1959) 176; Svetozar, Vukmanović - Tempo, Revolucija koja teče, v IV (Zagreb: Globus, 1982), 77.

${ }_{4}^{4}$ Josip, Broz Tito, Govor na Trećem kongresu Saveza komunista Srbije, Govori i članci, v IX (Zagreb: Naprijed, 1959), 136.

${ }^{5}$ Lorejn, Liz, Održavanje Tita na površini. Amerika, Jugoslavija i hladni rat (Belgrade: BMG, 2003),73; Yugoslavia in 1946, Robert, Jarman, Yugoslavia. Politicial Diaries 1918 1965, v III (London: Archive Edition Ltd, 1997), 742.

${ }^{6}$ Brian, Eichengreen, The European Economy since 1945. Cooridinated Capitalism and Beyond, (Princeton \& Oxford: Princeton University Press, 2007), 142.

${ }^{7}$ Zakon o Petogodišnjem planu razvitka narodne privrede Federativne Narodne Republike Jugoslavije, Službeni list Federativne Narodne Republike Jugoslavije, 30. 4. 1947.
} 
something of a 'permanent war economy'8 and the development of heavy industry were not only of economic, ideological and doctrinal nature. Concentration of all economic power, control over economic development, the ruining of agriculture and rural areas in order to facilitate industrialization had a clear political motivation. Incorporation of the private sector in economic planning and its subsequent complete liquidation was seen as a triumph of the Party. By isolating and economically ruining the pre - war elite, Yugoslav communists defeated their potential opponents and secured the regime. On the other hand, in an atmosphere of tension and constant incidents with the Western powers, only a self-sufficient economy based on heavy engineering, metallurgy and electronics guarantied military security, and thus the political stability of the regime. According to the official data presented by Tito, as much as 5 billion and 623 million dollars were invested in industry in the $1947-1952$ period. ${ }^{9}$ However, such huge investments were not nearly enough to cover expenses for the ambitious projects envisaged by the Five Year Plan. Moreover, the initial calculations used to underestimate the real costs of construction of and equipment for the planned facilities. ${ }^{10}$ Thus, (over)ambitious investment projects devoured nearly thirty percent of the national income. ${ }^{11}$ In such atmosphere, even the Party officials were aware that the country was being industrialized 'against economic laws and their nature'12

In order to fulfill daily quotas delivered by the Plan, Party officials believed that it was important to build, regardless of the financial and technical capabilities and the quality of workforce. With romantic fervor, they believed that enthusiasm and great sacrifice can overcome all obstacles. Construction statics should be subordinated to our political goals and the fulfillment of the plan", explained Party official, Batrić Jovanović, during his visit to New Belgrade construction site. ${ }^{13}$ Such notions led to improvisations. In the spring of 1947, the building of the industrial plants envisaged by the Plan started although 'definitive projects and operational plans' were not completed. This practice was so widespread that even Josip

${ }^{8}$ Brian, Eichengreen, The European Economy since 1945. Cooridinated Capitalism and Beyond, (Princeton \& Oxford: Princeton University Press, 2007), 136.

${ }^{9}$ VI Kongres Komunističke partije Jugoslavije (Saveza komunista Jugoslavije) 2-7. novembra 1952. Stenografske beleške, (Belgrade: publisher unknown, 1952), 63.

${ }^{10}$ Industrija (31. 12. 1953), Archive of Josip Broz Tito (in further text A JBT), KPR, III $-\mathrm{a}-4-\mathrm{a}$.

${ }^{11}$ Obim investicija i nacionalni dohodak, Archive of Yugoslavia (in further text AJ), $130-926-1411$.

${ }^{12}$ Zapisnik sa sednice kod predsednika Privrednog saveta Vlade FNRJ po pitanju robnog prometa, održane 17. i 18. avgusta 1951, AJ, 40-6-11.

${ }^{13} \mathrm{AJ}, \mathrm{A}$ CKSKJ, V, k - IV / 30. 
Broz Tito had to acknowledge that the construction of 'almost all objects' started without 'definite architectural plans' and building permits. The reason for such haste was simple - Five Year Plan was so unrealistic that even the Party leaders secretly feared that the deadlines would not be met. As the projects were developed 'in parallel with the construction work, and sometimes after it', improvisations led to drastic changes - for instance, a factory that manufactured construction machinery was originally envisaged as a facility for the production of iron barrels, while a hydraulic machinery factory was 'modified' into a plant specialized in manufacturing machinery and equipment. The price of this experimenting and improvising during the construction process was dear - scarce financial means were wasted as the cost of such ill-conceived construction was three times higher then expected. ${ }^{14}$

Rapid industrialization was accompanied by a chronic labor shortage. Patriarchal attachment to the village and agriculture, difficult working conditions, low wages and low money value were the main reasons because of which the peasantry refused to seek employment in factory halls and on socialist construction sites. Boris Kidrič, a senior Party official in charge of planned economy, tried to explain that the lack of workforce was 'inevitable' in early socialism. ${ }^{15}$ In order to overcome the difficulties which hindered the construction of socialism in the country, Party leaders tried to convince the Yugoslav youth to tie their future to factory halls. Therefore, all Party structures, from the top to the very bottom, were engaged in agitation and mobilization of workers. The Central Committees of the Party in all Yugoslav republics were ordered to 'popularize' certain branches of heavy industry and mining through the media, while the district committees of the People's Youth Organization were given the task to organize a series of lectures which would be held by 'the best workers and shock workers'. The Party demanded 'concrete agitation' - during the organized visits to industrial plants young men and women were (often falsely) informed about factories and a daily routine of the socialist workers. Since mobilization of the new laborers was an imperative, amateur cultural groups organized by Trade Union were ordered to perform in the villages and to use every opportunity to persuade peasants to find employment in industry. $^{16}$

${ }^{14}$ Ivana, Dobrivojević, Selo i grad. Transformacija agrarnog društva Srbije 19451955 (Belgrade: Institut za savremenu istoriju, 2013), 110-111.

${ }_{15}$ Boris, Kidrič, O zadacima štampe u borbi za plan, Sabrana dela, v VI (Belgrade: Komunist, 1985), 10.

${ }^{16}$ Plan agitacije za uključenje seoske omladine u privredu. Mere koje treba da preduzmu centralni komiteti narodnih republika; AJ, 25 - 152 - 403 
Party slogans about the necessity of industrialization and a better life in the 'new' socialist society were not popular in the Yugoslav countryside. The peasants believed that the industrial work was 'unworthy' ${ }^{17}$ and 'degrading'. ${ }^{18}$ Moreover, the employment of girls and young women was regarded as disgrace, since it was believed that they would become 'immor$\mathrm{al}^{\prime} .{ }^{19}$ However, despite all problems, Party leaders were not ready to consider the reduction of quotas envisaged by the plan. Those had to be achieved, despite the lack of financial resources, construction material ${ }^{20}$ and workforce. Faced with difficulties and afraid of (political) consequences, factory managements from all over the country were sending dramatic warnings to the officials, stating that lack of manpower represented a serious obstacle for fulfilling the Plan. Primitive and ill-organized production processes and low productivity (along with the unrealistic quotas) accounted for the constant demand for more and more workers. In Serbia alone during 1948, factories lacked 128000 men. ${ }^{21}$ In such circumstances, in the spring of 1948, the authorities turned to the formation of formally voluntary, but in fact often forced, work brigades that consisted mainly of peasants and members of the People's Front. In the struggle for Plan', special contribution and commitment was expected from the young people whose attitude towards work was considered as the essential criterion for evaluating 'the value of the youth'. ${ }^{22}$ The brigades had from thirty to several hundred people and were mostly used in forestry, road construction, cultivation of state owned farms, afforestation, melioration works etc. In 19481949, the Party heavily relied on work brigades. According to the official statistics, only in the course of 1949 more then a million Yugoslavs were mobilized into brigades. ${ }^{23}$

Although the work in the brigades was supposed to be voluntary, the socialist reality differed from the proclaimed ideal. The People's Front was turned into a 'non - voluntary' organization the main 'agenda' of which was to secure the massive participation in the brigades. In 1949, Party cadres openly recognized that 'voluntary principle' was brutally disregarded

${ }^{17}$ Cvetko, Kostić, Bor i okolina (Belgrade: Prosveta, 1962), 110-111.

${ }^{18}$ Cvetko, Kostić, Seljaci industrijski radnici (Belgrade: BIGZ, 1955), 212 - 214.

${ }^{19}$ Ibidem, 171- 73 .

${ }^{20}$ Zapisnik sa sastanka proširenog Biroa CK KP Srbije od 29. maja 1948, Archive of Serbia (in further text AS), Đ2 - Politbiro (without the number) - newly formed folder (without the number).

${ }^{21}$ Zapisnik sa sastanka proširenog Biroa CK KP Srbije od 29. maja 1948, AS, Đ2 Politbiro (without the number) - newly formed folder (without the number).

${ }^{22}$ Pero, Pirker, O borbi protiv nekih negativnih pojava kod omladine, Narodna omladina (February 1952).

${ }^{23}$ Ivana, Dobrivojević, Selo i grad. Transformacija agrarnog društva Srbije 19451955 (Belgrade: Institut za savremenu istoriju, 2013), 125-126. 
during the mobilization. 'It was only a question' whether the activists violated the proclaimed voluntary principle 'more or less severely'. ${ }^{24}$ In order to persuade young peasants to join the brigades, the zealous officials of the People's Front turned for help to the police. ${ }^{25}$ Detentions without the court order and various harassments were the price that young people and their parents had to pay for refusing to participate in the brigades. ${ }^{26}$ Although the Party leaders constantly warned junior officials that the "voluntary principle' should be respected, these admonishments were purely rhetoric. The Regime never tried to stop forced mobilization or at least alleviate the reprisals faced by the disobedient. In reality, sanctions applied to the oppressive activists were minimal, and a verbal reprimand was usually a sole punishment for the offenders. ${ }^{27}$ The oppression was thus only encouraged by the government. Moreover, in a socialist society ideology was much more important than the rule of law. In the eyes of the authorities, 'the lack of political work in many work brigades' was far more concerning than the brutal reprisals towards the people unwilling to participate in the hastened industrialization. ${ }^{28}$ However, by the end of 1949 even the Party leaders realized that forced mobilization of peasants caused serious 'political damage'. Boris Kidrič further elaborated that 'the notion that the country could be industrialized with peasant youth brigades was theoretically completely wrong'. ${ }^{29}$ The conflict with the USSR that culminated in 1949 and the complete reversal of foreign policy that followed led to a slow, but still noticeable, liberalization starting since 1950. A slight decentralization, loosening of the state control over economy, efforts to improve production and quality of goods and the prevailing notion that the 'real' workers had to be employed in the industry, led to the gradual demobilization of the brigades.

However, the brigades organized by the People's Front were not the only ones in which young men and women were supposed to build socialism. In 1946-1952, the Party organized federal and local 'youth work actions' in which peasants, pupils and students as well as young workers took part. According to the official statistics (which are highly dubious for the

${ }^{24}$ Savetovanje uprave za radne brigade pri Saveznom odboru Narodnog fronta sa rukovodiocima i sekretarima uprava za radne brigade pri glavnim odborima i sekretarima uprava pri oblasnim odborima održanog 20. oktobra 1949. godine u Beogradu, AJ, $142-$ $28-84$.

${ }^{25}$ Ibidem.

${ }^{26}$ Izveštaj komisije od 17. avgusta 1948. godine, AS, Đ4 - 2 .

${ }^{27}$ Ibidem.

${ }^{28} \mathrm{O}$ političkom radu od Drugog plenuma, AS, Đ2 - 13-10.

${ }^{29}$ Boris, Kidrič, O privrednim problemima u vezi sa budžetom, Sabrana dela, v VI (Belgrade: Komunist, 1985), 29. 
given period) more than a million of youngsters built 70 facilities. 1 May 1946 was a symbolically chosen date for the beginning of the first work action in which the Brčko-Banovići railway was constructed. In the following year one more railway (connecting the towns of Šamac and Sarajevo) was built. However, in December 1947, the Central Council of the People's Youth decided to organize a 'work action' in each of the Yugoslav republics in order to provide for free workforce but also to 'include young people, help them interact and share experiences'. Still, for the Party officials the political and ideological content of 'work actions' was far more important than economic gains. These manifestations provided an opportunity for 'a comprehensive political - economic and cultural education', 'the strengthening of love for the socialist country' and endorsing the ideology of 'fraternity and unity'. Moreover, the 'work actions' were perceived as an ideal chance for the 'recruitment' of the new labor force that the developing Yugoslav industry chronically lacked. However, the youth was not too eager to participate in these manifestations - many young men and women joined the youth brigades neither willingly nor voluntarily. The attitude towards youth brigades differed from one republic to another. Bosnia and Herzegovina had the highest turnout of the youth willing to participate in the 'work actions'. On the other hand, the 'recruitment' in Serbia and Croatia was sometimes carried out through mobilization calls. Moreover, pupils could not continue their high school or university education without the certificate of participation. ${ }^{30}$ Since gathering as many participants as possible was essential, Party officials did not care much about the serious sideeffects of 'work actions'. Paradoxically, instead of boosting economy and construction, forced mobilization caused serious damage. It turned out that the cheap labor was not that cheap after all. Unskilled and inexperienced temporary workforce was neither capable nor motivated to work efficiently and cost-effectively. Moreover, in many villages fields were left uncultivated and factory halls emptied since some permanently employed young workers were threatened that they would be fired if they refused to join youth brigades. ${ }^{31}$ Even the fourteen-years-old children were sent to the socialist construction sites, along with the 'physically weak youngsters' ${ }^{32}$ Nevertheless, by the spring of 1949, neither of the republics managed to gather enough youth workforce for the 'work actions'. Paradoxically, sometimes the district committees of the Communist Party also refused to send

${ }^{30}$ Ivana, Dobrivojević, Selo i grad. Transformacija agrarnog društva Srbije 1945 1955 (Belgrade: Institut za savremenu istoriju, 2013), 132- 33.

${ }^{31}$ Izveštaj sa obilaska gradilišta Magnohroma u Rankovićevu i valjaonice bakra u Sevojnu (1952), AS, Đ2 - 1.

32 Zapisnik sa savetovanja zemaljskih veća Narodne omladine odgovornih po propagandi i agitaciji održanog 28. aprila 1948. godine; AJ, 114 - 76. 
youngsters to work in the brigades outside their territory. The reasons for such behavior were of practical rather than ideological nature. Afraid of the possible sanctions if they failed to meet their quotas, ${ }^{33}$ low ranking Party cadres sought to 'mobilize' the youth for local 'work actions'. ${ }^{34}$ Thus, in the bleak atmosphere in the society in which everything was subordinated to the fulfillment of the Plan, repression exercised by the state was a constant threat not only for the non - sympathizers of the regime, but also for the low ranking officials.

In spite of the repressive measures, many young men from rural areas refused to participate in the youth brigades, since they perceived this kind of engagement as a 'toil and moil'. ${ }^{35}$ Openly and without any hesitation, some opposed the authorities, stating that they did not want to go as they had already participated in 'work actions'. Others asked for the order issued by the 'people's government', stating their willingness to work in the youth brigades 'forever', if presented with such document. ${ }^{36}$ Those who joined the brigades sometimes 'deserted' from the socialist construction sites. According to the official statistics, around $2 \%$ of the youth engaged in building New Belgrade left the construction site and went home. ${ }^{37}$ However, Party slogans about the bright future and the pompously announced struggle for the universal progress, ${ }^{38}$ aroused faith, hope and enthusiasm, especially among the youth willing to contribute to the transformation of the society.

While some saw the 'work actions' as a chance to change the society, others perceived it as an opportunity to earn the shock worker's badge and the additional rationing coupons. Musician Krsta Popovic latter recalled: 'The enthusiasm of the youth was extraordinary. No one asked for a special diet or enquired about the living conditions in the brigades. Young men and women worked with such a pace as if communism would arrive tomorrow! Shock workers were rewarded with 60 rationing coupons. For 30 coupons a brand new suit could be bought, while the sneakers in the

${ }^{33}$ Iz izveštaja Javnog tužilaštva NR Hrvatske od 10. 10. 1950, AJ, 25 - 154-407.

${ }^{34}$ Zapisnik sa sastanka proširenog Biroa CK KP Srbije održanog 28. maja 1948, AS, Đ2 - Politbiro (without the number) - newly formed folder (without the number).

${ }^{35}$ Izveštaj sa službenog puta Popović Dragoljuba, službenika Savezne uprave za radnu snagu po putnom nalogu br. 386 / 48 a po pitanju uključenja radne snage u rudarstvo Bosne i Hercegovine (22. 11. 1948); AJ, 25 - $153-405$.

36 Izveštaj sa obilaska terena srezova Pocerskog, Mačvanskog i Posavskotamnavskog od 19 - 26. oktobra 1950; AJ, $114-382$.

${ }^{37}$ Slobodan, Selinić, Omladina gradi Jugoslaviju. Savezne omladinske radne akcije u Jugoslaviji 1946-1963, Arhiv, (1-2) 2005, 97.

${ }^{38}$ Ostvarimo socijalizam u našoj zemlji, J. B. Tito, Govori i članci, v. V (Zagreb: Naprijed), 8 . 
Borovo store cost another 15. Popularity was guaranteed by the mere possession of these items'. ${ }^{39}$

Party officials believed that the youth brigades were a valuable and inexhaustible source of labor force. Kidrič stressed that 'young people learn quickly' and thus young workers would become 'the pioneers of heavy industry'. ${ }^{40}$ The agitators from industrial plants all over Yugoslavia roamed through the construction sites in search of work force. Meanwhile, the barely literate rural youth attended brief courses to acquire 'qualifications' for the industrial work. Since the main objective was to convince young people to seek for permanent employment in the industry, false promises became the central means of agitation. Young men and women were promised a comfortable life in factories, good accommodation and food, new clothes and shoes, while the real nature of work, especially physical, was completely concealed from them. A number of the newly employed youngsters did not even know the location of a factory they were supposed to work in. ${ }^{41}$

False representations and glossing over the reality produced the initial results. Deceived by the stories of prosperity and better life, the poorly educated youth signed the contracts with company representatives. Therefore, the quotas of young workers were easily fulfilled and even exceeded. ${ }^{42}$ Although the authorities warned that the recruitment of work force should be more careful, the employment was given to everyone, including immature children and physically underdeveloped and weak men. However, the success was only temporary. The youth could not be permanently won over by embellishments and deceits. Party officials helplessly stated that 'young people were coming to the factories and mines poorly prepared, looking for the opportunity to escape'. ${ }^{43}$ On one occasion only 6 out of 150 new employees decided to stay at work. ${ }^{44}$ Aware of political damage and high financial cost caused by these escapes, Party leaders instructed the agitators not to embellish working conditions in socialist factories. Thus, the youth was now informed in advance about the problems they would encounter in factories and given the explanation that these difficulties were only temporary. ${ }^{45}$

${ }^{39}$ Petar, Luković, Bolja prošlost. Prizori iz muzičkog života Jugoslavije, (Belgrade: Mladost, 1989), 131.

${ }^{40}$ AJ, $25-152-403$.

${ }^{41}$ Ivana, Dobrivojević, Selo i grad. Transformacija agrarnog društva Srbije 19451955 (Belgrade: Institut za savremenu istoriju, 2013), 210-211.

${ }_{42}$ Za bolje prihvatanje omladine koja sa radnih akcija odlazi u privredu (1949); AJ, 114 - 72.

${ }^{43}$ Izveštaj o radu Narodne omladine za 1949, AS, Đ2 - 16 - 8.

${ }^{44}$ Problematika o uključenju omladine $\mathrm{u}$ privredu sa radnih akcija na autoputu i Novom Beogradu, AJ, 25 - 152 - 403.

${ }^{45}$ AJ, $25-152-403$. 
Party leaders could not easily resign themselves with disinterest, indifference and lack of enthusiasm of the vast part of Yugoslav population towards the work in industrial plants and socialist construction sites. Since political slogans and embellished reality could not motivate the youth to find employment in industry, Party leaders turned to 'administrative solutions'. This euphemistic term had its hidden repressive content. The workforce quotas required by the Plan had to be met in one way or another. Thus, local Party authorities were given precise orders regarding the number of people who had to be taken to work. ${ }^{46}$ Although the Party leaders officially instructed local authorities not to use force but rather to 'politically persuade' the people to work, these orders were mere rhetoric. On one hand, the Party generally condemned repressive measures, but the perpetrators were never punished. On the other hand, local authorities feared that they would be scrutinized, criticized and openly exposed in the press. District officials thus represented the scapegoats who were supposed to accept all the responsibility for any failure of the plan. High-ranking Party leaders concluded during a session of the Economic Council: 'Criticism should exist and [it should be] supported by concrete facts. ${ }^{47}$ With their back against the wall, some District Committees tried to resist, explaining that there was not enough work force, ${ }^{48}$ while the others turned to intimidations, terror and coercion. A local Party official from the Niš district openly acknowledged: 'New laborers cannot be obtained with persuasion and political agitation. Thus, they should be put under pressure' ${ }^{49}$ His perception was widespread and police took an active part in the mobilization of work force.

Although Party leaders constantly emphasized the fairness of a socialist society which took care of its people ${ }^{50}$ the bleak reality of young workers confuted political slogans. Paradoxically, the great poverty and forced mobilization for work in industry did not improve the attitude of factory boards towards the newly employed. Meals at the factory canteens had to be paid in advance (before the first wage) and thus even food was a luxury which many of the youngsters could simply not afford. In a factory in Zemun, the cook tried to take off the coat from one of the employees because 'he had lunch although he did not buy a coupon for the meal'. It

${ }^{46}$ Izveštaj o radnoj snazi, AJ, 25 - 154- 406.

${ }^{47}$ Zabeleška sa sednice održane na dan 17. jula 1949. godine kod predsednika Privrednog saveta druga Kidriča Borisa, $40-4-9$.

${ }^{48}$ Izlaganje Miće Zorića na II plenumu CK KPS održanom 30. i 31. maja 1949, AS, Đ2 - 2-1.

${ }^{49} \mathrm{O}$ političkom radu od II plenuma 1949, AS, Đ2 - $13-10$.

50 Josip, Broz Tito, Zadatak socijalističke države jeste da vodi brigu o ljudima, Govori i članci, v VI, (Zagreb: Naprijed, 1959), 207 - 208. 
was even worse destiny awaited for the feeble and unhealthy young men. Although they were recruited for factory work, the company management refused to hire them due to their weak physical constitution and deteriorating health. The boys who failed to find employment in the Kreka mines had to sell their own clothes and shoes in order to pay for their rides back home. The official Party reports refer to numerous young men roaming the streets of Belgrade, Sarajevo, Zagreb and Ljubljana and begging for food and money to return to their villages. ${ }^{51}$

General poverty and low level of education, along with the failures of factory managements and local authorities, resulted in difficult working conditions in the industrial plants. Companies did nothing to provide decent housing for their workers. Although Party slogans always glorified physical labor, laborers were forced to live in gloomy conditions. The quality of life in the primitive and provisory factory colonies was miserable. Humanitarian socialist society did not care much about the workers, 'heroes of socialism' and 'shock workers', the stories of whom filled the columns of newspapers, were practically forced to live on the very margin of society.

Official reports chronicled similar dreary living conditions across Yugoslavia. Small and cramped rooms, stuffy barracks, overall lack of hygiene, malnutrition and neglect, lice, bugs, mice, unwashed linen, dirty and torn clothes were some of the adversities that the residents of factory huts faced on a daily basis. 'Their dwelling facilities are very poor', stated a typical report. 'It often happens that 90 people live in the premises which can accommodate up to $30 \ldots$

The smell in these areas is almost unbearable'. The wagon factory from the town of Kraljevo accommodated the newly employed youth in the attic of a blacksmith shop in which 'smoke penetrated, choking the youngsters'. ${ }^{52}$ Meanwhile, young workers had to sleep on the 'bare floor' in the Bosnian town of Zenica.

However, in some cases, culture and quality of life was, at least to some extent, determinated by personal hygienic habits. Despite the general squalor around workers' huts on the Drina river, the yards around barracks in which Slovenians and Hungarians lived were well-kept. The workers were aware of the problem. 'Everything was nice and clean, the rooms were painted', stated an employee from a cement factory. 'However, we ourselves do not take care of cleaning, so it cannot be clean. We go to bed in the working clothes. We do not pay or are willing to pay for accommodation'.

${ }^{51}$ Uključivanje omladine u privredu i stručne kurseve (bez datuma); AJ, 114 - 152.

${ }^{52}$ Ivana, Dobrivojević, Selo i grad. Transformacija agrarnog društva Srbije 19451955 (Belgrade: Institut za savremenu istoriju, 2013), 222. 
The company management tried to hire a cleaning lady, but the workers 'strongly protested', refusing to sleep in the dorms. ${ }^{53}$

The Party authorities believed that provisional workers' huts were not only a 'necessary evil', but also the 'centers of immoral offences'. ${ }^{54}$ Dreary living conditions, low wages, the collapse of the old patriarchal norms and lack of control, along with the negative impact of the older workers, kept young men and women to the very bottom of the social ladder. Moreover, the socialist society did not have anything to offer to the youth who migrated from the countryside. Low salaries were barely sufficient for food, ${ }^{55}$ but not for any leisure activities. Ideological education was thrust upon the workers Political lectures, 'red corners' and empty promises represented the embodiment of the 'cultural revolution' and enlightenment promised by Party slogans. The general poverty and the lack of cultural and leisure facilities crucially affected the everyday life of young laborers. In Mladenovac, the industrial town near Belgrade, 'young workers did not have a place to go to after the working hours, so they stayed in the streets until late at night'. ${ }^{56}$ In these circumstances, alcoholism, prostitution, gambling, fighting and swearing were typical features of factory colonies. $^{57}$

Poverty and ignorance, along with the transformation of gender relations and greater sexual liberties, led to brief and casual affairs that were condemned by the patriarchal society. Collective housing blurred the boundaries of intimacy and privacy and young people often came to conclusion that such boundaries were superfluous altogether. In some workers' settlements in Belgrade it was reported that 'girls [were] bringing young men to shared rooms ... and having sexual intercourse in full view of everyone'. ${ }^{58}$ 'It is painful to talk about morality' chronicled Omladina (Youth). 'During the working hours laborers swear, tell dirty jokes and talk about lascivious adventures', and thus the factory halls became 'the school of debauchery'. ${ }^{59}$

${ }^{53}$ Ivana, Dobrivojević, Selo i grad. Transformacija agrarnog društva Srbije 1945 1955 (Belgrade: Institut za savremenu istoriju, 2013), 219-221.

${ }^{54}$ Moralno vaspitanje omladine; AJ, $114-76$.

${ }^{55}$ Analiza života i rada radničke omladine, AJ, 114 - 92.

${ }^{56}$ Izveštaj o stanju radničke omladine u Mladenovcu, AJ, $114-382$.

${ }^{57}$ Ivana, Dobrivojević, Između ideologije i pop-kulture. Život omladine u FNRJ 1945-1955, Istorija XX veka, 1 (2010), 123.

${ }^{58}$ Ivana, Dobrivojević, Urbanization in Socialism. Everyday life in Yugoslav Towns 1945-1955, in Katrina Gulliver, Helena Toth ed, Cityscapes in History. Creating the Urban Experience (London: Ashagate, 2014), 89.

59 "U ličnom životu mladih radnika leži ključ rešenja mnogih problema", Omladina (8. 10. 1952). 
Difficult living and working conditions, low and irregular earnings, ${ }^{60}$ physical exhaustion at work and frequent injuries were the main reason why the newly employed workers, unaccustomed to industrial work and unmotivated, easily and frequently changed their jobs. Due to the poor organization of the production process, high quotas required by the Plan, ignorance and lack of motivation among the workforce, socialist plants were constantly looking for the new laborers. Thus, employment opportunities in the first post-war years were practically limitless. Moreover, unskilled workforce dominated on the labor market, so practically everyone was 'able' to work everywhere. In such circumstances, the much desired reduction of production costs and the increase in productivity could not be achieved. ${ }^{61}$

Moreover, a vast number of young men and women, who were fooled by unrealistic promises of better life, left industrial plants and returned to their villages after few weeks of work. ${ }^{62}$ According to the official data, 939200 workers were employed during the first ten months of 1949. However, only 182000 of them retained their jobs. ${ }^{63}$ Although the number of the newly employed was rising steadily, the developing industry suffered from the fluctuation of workforce. Even the official Party organ Borba admitted 'in an unusually sincere article', that in $97 \%$ of workers left the Bor mines in 1949.

The reason for their leaving the job was simple - the wages were not sufficient to meet monthly expenses. ${ }^{64}$ In the entire Serbia, during the same year every production worker was replaced by another one. ${ }^{65}$ This widespread fluctuation could not be controlled or diminished by the strict regulations. Although it was stipulated that the workers could not leave their jobs, such cases were rarely reported to the authorities. Aware of the regulations, the workers themselves were careful to avoid sanctions. Some worked under false name, while others gave inaccurate personal data to the company officials. However, in times of severe state repression the company management was afraid of the authorities just as much as the workers

${ }^{60}$ Izveštaj sa obilaska partijske organizacije građevinskih preduzeća u Nišu i preduzeća Hidrogradnje, A CK SKJ, V, k- IV/ 59.

${ }^{61}$ Radmila, Radić, Društveno-ekonomski položaj radničke klase u Srbiji od 1945. do 1950, Tokovi revolucije, XX - XXI (1988), 65.

${ }^{62}$ Nezavedeno, bez datuma, iz 1949, AJ, 25-152- 403.

${ }^{63}$ Sa savetovanja članova biroa CK Narodne omladine Jugoslavije i CK Narodne omladine republika po pitanju rada sa radničkom omladinom (7. 10. 1949); AJ, 114 - 58.

${ }^{64}$ Yugoslavia: Fortnightly Summary. Period ending 16th February, 1950, R. Jarman, Yugoslavia: Political Diaries 1918 - 1965, v IV (London: Archive Edition Ltd, 1997), 147.

${ }^{65}$ Radmila, Radić, Društveno-ekonomski položaj radničke klase u Srbiji od 1945. do 1950, Tokovi revolucije, XX - XXI (1988), 57. 
were - according to the regulations, directors should have been held responsible if they had failed to prevent the fluctuation. ${ }^{66}$

Due to the slow, but visible, changes in economic policy, the number of employed workers was constantly decreasing from 1950 onwards. By the end of 1951, the unemployment had become an issue, particularly in large cities. Young and unskilled workers were most affected by the joblessness. The more rational use of work force, the relative increase in productivity, mass migrations, but also the decline of crafts, the ruin of the tertiary sector and severe drought, which all combined to increase the pressure on cities, were some of the main causes of unemployment. In order to solve the emerging problem, the government organized public works, limited overtime working hours, tried to boost investments on the regional level and introduced some changes in taxation. ${ }^{67}$ Still, these measures had only temporary effect. To solve the problem, it was necessary to undertake serious structural changes - the modification of investment policy, the development of manufacturing industry and services, better educational structure of the employees, but also the improvement of living standard to increase the spending which would, in turn, stimulate production. Moreover, it turned out that mass migrations (that started involuntarily) could not be stopped or controlled. The data collected in a survey from 1957 showed that $70 \%$ of the (mostly unqualified) youth wanted to move to the cities in order to find an employment. ${ }^{68}$ Thus, in the course of only one decade the problem of underemployment turned into the problem of unemployment. Unprepared and incapable of undertaking structural reforms, Party leaders had to seek for a different solution. In October 1956, the Federal Executive Council cautiously and timidly considered the possibility of 'exporting' the surplus workers abroad, since the French and Luxembourg officials approached the Yugoslav authorities looking for inexpensive and largely unskilled workforce. ${ }^{69}$ However, political considerations and concern for the reputation of a socialist country in the world delayed the decision to address the accumulated economic and social problems by sending unskilled rural labor force to the Western European countries until $1963 .^{70}$

${ }^{66}$ Ivana, Dobrivojević, Selo i grad. Transformacija agrarnog društva Srbije 19451955 (Belgrade: Institut za savremenu istoriju, 2013), 225-226.

${ }_{67}$ Kratak izveštaj o nezaposlenosti, A JBT, KPR III - A - 1- e.

${ }^{68}$ Anketa CK Narodne omladine Jugoslavije sprovedena od 15. 10 do 4. 11. 1957. među seoskom omladinom; AJ, $114-95$.

${ }^{69}$ Informacija o pitanju upošljavanja naših radnika u inostranstvu, Problemi životnog standarda, A JBT, KPR III - A - 1 - e.

70 Ivana, Dobrivojević, U potrazi za blagostanjem. Odlazak jugoslovenskih državljana na rad u zemlje zapadne Evrope, Istorija 20. veka, 2 (2007), 89-100. 
Ivana Dobrivojević

\section{(NE)DOBROVOLJNI GRADITELJI SOCIJALIZMA: MLADI RADNICI U RANOM PERIODU SOCIJALISTIČKE JUGOSLAVIJE}

\section{Rezime}

U jednoj od najzaostalijih evropskih zemalja, sveukupna društvena modernizacija, oličena pre svega $u$ industrijalizaciji i urbanizaciji, predstavljala je istorijsku nužnost. Partijska shvatanja o ulozi i značaju omladine, dominantno ruralni karakter jugoslovenskog društva, nedostatak kvalifikovanih radnika, ali i entuzijazam i želja za obnovom zemlje, najprisutniji među mladima, uticali su da omladina, pre svega ona sa sela, podnese najveći teret obnove i modernizacije zemlje. Ipak, patrijarhalna vezanost za zemlju i zemljoradnju, teški uslovi života i rada u fabrikama i na socijalističkim gradilištima, niske nadoknade, ali i shvatanja da nema veće nesreće za seosku devojku od zaposlenja u industriji, odbijali su mnogo omladine od odlaska u grad. Suočeni sa stalnom nestašicom radne snage, partijski čelnici su se okrenuli mobilizaciji mladih za odlazak u frontovske brigade, na radne akcije ili u uključivanje u industriju - bilo kao privremena, bilo kao stalna radna snaga. U prvim posleratnim godinama na ovakav rad se gledalo kao na kuluk, pa ni pretnje kaznama i prinudna mobilizacija nisu davali željene rezultate. Iako su već od početka 1950-ih godina pojedini ekonomisti upozoravali da organizovanje radnih akcija skupo staje državnu kasu, a da od rada mladih koji nisu poznavali prirodu građevinskog posla najčešće nema previše koristi, sa omladinskim akcijama se nastavilo i posle kraćeg prekida 1952. godine. Liberalizacija u zemlji, odmakla društvena modernizacija, bolji uslovi života u gradovima, kao i sve veće zaostajanje poljoprivrede $\mathrm{i}$ sela u celini, kao rezultat višegodišnjeg maćehinskog odnosa vlasti prema agraru, uticali su i na promenu shvatanja mladih. U početku prinudno pokrenut prelazak zemljoradnika $u$ industriju i migracije na relaciji selo - grad bilo je teško kontrolisati, budući da je već od polovine 1950-ih godina najveći broj mladih pokušavao da završi neki od kurseva i pronađe posao u gradu. 